\title{
KEARIFAN LOKAL MASYARAKAT DALAM UPAYA PENGELOLAAN SUMBERDAYA AIR DESA LEREP,KECAMATAN UNGARAN BARAT, KABUPATEN SEMARANG
}

\author{
Eppy Yuliani ${ }^{1}$ \\ Megita Aprilina $^{2}$ \\ Prodi Perencanaan Wilayah dan Kota, Fakultas Teknik, UNISSULA ${ }^{1,2}$ \\ Penulis Korespondensi e-mail : eppy@unissula.ac.id
}

ABSTRACT

Lerep Village, West Ungaran District, Semarang Regency is located not far from the of Ungaran City, it has the potential of agriculture, plantations and tourist villages. In addition to this potential, Lerep Village has a local wisdom practiced by the community for generations. The Iriban tradition is one of the local wisdoms aimed at managing water resources in Lerep Village. This study aims to find forms of local wisdom in efforts to manage water resources. The research method used is to use qualitative methods with a rationalistic approach. The rationalistic approach emphasizes reason in an analysis process. The conclusion of this research is form of local wisdom Iriban is a community effort in managing water resources for community life both for household and agricultural interests.

Keywords: wisdom, local, management, water resources.

\begin{abstract}
ABSTRAK
Desa Lerep, Kecamatan Ungaran Barat, Kabupaten Semarang letaknya tidak jauh dari pusat kota Ungaran, memiliki potensi pertanian, perkebunan dan desa wisata. Selain potensi tersebut, Desa Lerep memiliki kearifan lokal yang dilakukan masyarakat secara turun temurun. Tradisi Iriban merupakan salah satu kearifan lokal yang bertujuan dalam pengelolaan sumberdaya air di Desa Lerep. Penelitian ini bertujuan menemukan bentuk kearifan lokal dalam upaya pengelolaan sumberdaya air. Metode penelitian yang digunakan adalah menggunakan metode kualitatif dengan pendekatan rasionalistik. Pendekatan rasionaltistik menekankan akal dalam suatu proses analisis. Kesimpulan dari penelitian ini adalah bentuk kearifan lokal Iriban merupakan upaya masyarakat dalam mengelola sumberdaya air bagi kehidupan masyarakat baik untuk kepentingan rumah tangga,maupun pertanian.

Kata kunci : kearifan, lokal, pengelolaan, sumberdaya air.
\end{abstract}


Jurnal Planologi Vol. 17 No. 1, April 2020

Available : http://jurnal.unissula.ac.id/index.php/psa

\section{PENDAHULUAN}

\subsection{Latar Belakang}

Setiap wilayah pedesaan memiliki karakter yang menjadi kekhasan dari kehidupan masyarakat di desa tersebut. Karakter ini muncul dalam ke hidupan masyarakat yang merupakan tradisi secara turun temurun selama beberapa masa sebelumnya hingga saat ini masih diaksanakan oleh masyarakat. Fenomena ini dapat dimaknai sebagai kearifan lokal atau local wisdom (Nasiwan, 2012). Banyak aspek yang dapat diangkat dalam pembangunan dan pengembangan desa dengan melihat potensi yang disesuaikan dengan ciri khas atau keaslian daerah tersebut.

Desa Lerep , Kecamatan Ungaran Barat, Kabupaten Semarang, Provinsi Jawa Tengah memiliki luas wilayah yang luas yaitu sekitar 682 Ha yang terdiri dari 64 RT, 10 RW dan delapan dusun. Potensi desa ini adalah pertanian, perkebunan dan wisata desa berbasis budaya masyarakat dan religi. (Mohamad Wakhyudin Juhadi, Heri Tjahjono, 2017). Salah satu Program pembangunan Desa Lerep yaitu melestarikan sumber daya alam untuk kesejahteraan masyarakat melaui tradisi “Iriban'. Iriban merupakan kearifan lokal yang selau dilaksanakan oleh masyarakat dalam upaya melestarikan sumberdaya alam. Tradisi iriban dilakukan masyarakat Desa Lerep setiap awal musim tanam padi.

Air merupakan sumber kehidupan , khususnya di wilayah pedesaan yang mana air tidak saja untuk kehidupan manusia melainkan untuk kebutuhan budidaya pertanian. Seperti firman Allah dalam Al Qur'an bagian surat Al Anbiyah ayat :30, yang artinya : dan air Kami jadikan segala sesuatu yang hidup.

Tujuan penelitian ini menemukan bentuk kearifan lokal dalam upaya pelestarian sumberdaya air. Sasaran penelitian : mengidentifikasi kearifan lokal desa Lerep ; menganalisis kearifan lokal Iriban dalam upaya melestarikan sumberdaya air. Pelestarikan sumberdaya air dilakukan untuk kesejahteraan masyarakat, hal ini dimaksudkan dalam menggali potensi yang ada di Desa Lerep dengan tetap menjaga kelestarian sumber daya alamnya (Aziz,2015).

\subsection{Kajian Teori}

Kearifan lokal adalah perilaku positif manusia ketika berinteraksi dengan alam dan lingkungan lokalnya yang berasal dari nilai adat religius mereka, nasihat nenek moyang atau budaya lokal, yang secara alami dibangun di dalam komunitas untuk beradaptasi dengan lingkungan lokalnya (Vitasurya 2016, 99). Sedangkan definisi lain dari kearifan lokal adalah upaya masyarakat untuk melestarikan sumber daya yang dapat digunakan 
terus menerus untuk memberi makan masyarakat dan menjaga keseimbangan lingkungan Secara konseptual, kearifan lokal merupakan bagian dari kebudayaan.(Sartika, 2018)

Kearifan lokal terbentuk dari dua kata yaitu kearifan yang artinya wisdom atau kebijaksanaan dan lokal yang berarti setempat. Kearifan lokal dapat di artikan gagasan dan pandangan yang sifatnya bijaksana dan baik tertanam dan dikuti oleh anggota masyarakat. Pengertian lain terkait kearifan lokal adalah pengetahuan asli di dalam masyarakat yang asalnya adalah nilai luhur kebudayaan untuk mengatur tatanan kehidupan (Sibarani,2012). Pakar Antropologi mengatakan bahwa nilai luhur kebudayaan itu adalah wujud hubungan manusia dengan lima hal seperti Tuhan atau yang diluhurkan, alam, sesama manusia, kerja dan waktu.

Sedangkan menurut Sunaryo et al (2003) kearifan lokal adalah pengetahuan lokal yang telah menyatu dengan kepercayaan, norma dan budaya yang kemudian di apresiasikan ke dalam bentuk tradisi dan mitos yang berkembang di dalam masyarakat dalam jangka waktu yang lama. Kearifan lokal bersumber dari nilai, kepercayaan atau agama, etos kerja dan dinamika (Sibarani, 2012).

Kearifan Lokal dapat diartikan sebagai semua warisan kebudayaan yang bersifat tangible dan intangible (Sedyawati, 2006). Kearifan lokal dapat dikategorikan ke dalam dua sifat yaitu adalah sebagai berikut :

\section{Tangible}

Atau kearifan lokal dengan bentuk nyata seperti :

a. Tekstual (sistem nilai dan tata cara dalam bentuk tertulis)

b. Bangunan atau arsitektural

c. Benda cagar budaya atau karya seni budaya

\section{Intangible}

Atau kearifan lokal yang tidak berbentuk seperti ajaran tradisional yang diteruskan secara turun temurun dari generasi ke generasi.

Bentuk suatu kearifan lokal disesuaikan dengan pandangan hidup suatu kelompok masyarakat karena kearifan lokal merupakan sarana dalam mengolah suatu kebudayaan yang berkembang sebagai suatu strategi kehidupan dalam wujud aktifitas masyarakat. Kearifan lokal memiliki fungi sebagai penanda suatu komunitas melalui unsur kultural, elemen perekat dalam hubungan manusia dengan nilai kebudayaan, bentuk keberagaman, untuk mengubah pola pikir dan hubungan timbal balik dan untuk membangun kebersamaan sesama masyarakat (Abdullah,2011) 
Dalam UU No 23 Tahun 2009 kearifan lokal adalah nilai yang berlaku di dalam tatanan kehidupan masyarakat yang bertujuan untuk melindungi sekaligus mengelola lingkungan hidup secara lestari. Dalam kata lain Kearifan lokal adalah wujud implementasi pengetahuan kebudayaan untuk pengelolaan sumber daya alam melalui pemanfaatan yang bijaksana(Widjono 1998 dalam Sedyawati 2006).

Pendekatan untuk melestarikan alam dapat berupa pendekatan politik ekologi dimana hal tersebut merupakan kajian sebab akibat dengan melihat isu lingkungan seperti right to environment atau persoalan relasi dan environment justice atau alokasi kepemilikan dengan mempertimbangkan generasi(sedyawati,2006)

\section{METODOLOGI}

Metode penelitian yang digunakan adalah menggunakan metode kualitatif dengan pendekatan rasionalistik. Metode Kualitatif adalah penelitian yang dilakukan dengan pendekatan dan implementasi secara kualitatif, dengan pengembangan perspektif yang beragam. Metode kualitatif berguna untuk pengkajian mendalam terhadap suatu histori dan kompleksitas dengan menghasilkan data deskripsi atau data berupa kata-kata (Bodgan\&Taylor 1975 dalam Basrowi 2008)

Pendekatan rasionaltistik menekankan akal dalam suatu proses analisis masalah dalam suatu penelitian, pendekatan tesebut menjadi sebuah instrumen utama dimana semua data yang dicari dengan cara survei primer melalui wawancara secara mendalam kepada narasumber terpilih (Muhajir, 1996). Responden terpilih diantaranya Aparatur Desa Wisata Lerep, Ketua BUMDes Lerep, Tokoh Masyarakat, Masyarakat Desa Wisata Lerep hingga mencapai komparasi atau perbandingan jawaban yang diinginkan.

\section{HASIL DAN PEMBAHASAN}

Desa Wisata Lerep adalah salah satu desa yang ada di Kecamatan Ungaran Barat Kabupaten Semarang. Desa Wisata Lerep merupakan desa dengan luas wilayah terbesar di Kecamatan Ungaran Barat, yaitu dengan luas kurang lebih 682Ha. Desa Wisata Lerep memiliki delapan dusun yaitu Dusun Karangbolo, Dusun Indrokilo, Dusun Lerep, Dusun Soka, Dusun Tegalrejo, Dusun Lorog, Dusun Kretek dan Dusun Mapagan.Lokasi Desa Wisata Lerep berada di ketinggian sekitar 30-940mpdl. Memiliki kelerengan sekitar 0-15\% dan termasuk ke dalam klasifikasi landai. Desa Wisata Lerep Memiliki suhu rata-rata sekitar $24-34^{\circ} \mathrm{C}$ serta memiliki curah hujan berikisar antara $2500-3000 \mathrm{~mm} /$ tahun dan 
termasuk ke dalam kelas curah hujan tinggi. Jumlah penduduk di Desa Wisata Lerep dalam kurun waktu lima tahun terakhir yang rata-rata mengalami peningkatan sperti tabel berikut ini

Tabel 1 Jumlah Penduduk Desa Wisata Lerep Dalam Lima Tahun Terakhir

\begin{tabular}{|r|r|r|r|}
\hline TAHUN & JUMILAH PENDUDUK & JUMILAH \\
\hline $\mathbf{2 0 1 4}$ & 5.054 & 5.155 & 10.209 \\
\hline $\mathbf{2 0 1 5}$ & 5.054 & 5.133 & 10.178 \\
\hline $\mathbf{2 0 1 6}$ & 5.454 & 5.496 & 10.950 \\
\hline $\mathbf{2 0 1 7}$ & 5.956 & 5.930 & 11.886 \\
\hline $\mathbf{2 0 1 8}$ & 5.258 & 5.221 & 11.970 \\
\hline Sumber: Kecamatan Ungaran Barat Dalam Angka, 2014-2018
\end{tabular}

Desa Wisata Lerep memiliki kepadatan penduduk rata-rata $1.491,72 \mathrm{jiwa} / \mathrm{Km}^{2}$. Untuk jumlah penduduk menurut pekerjaan di Desa Lerep pada tahun 2018 adalah sebagai berikut ini.

Tabel 2 Jumlah Penduduk Menurut Pekerjaan di Desa Wisata Lerep

Tahun 2018

\begin{tabular}{|lr|}
\hline \multicolumn{1}{|c}{ JENIS PEKERJAAN } & \multicolumn{2}{c|}{ JUMLAH } \\
\hline Belum/Tidak Kerja & 2.543 \\
\hline Mengurus Rumah Tangga & 743 \\
\hline Pelajar/Mahasiswa & 2.120 \\
\hline TNI dan Polri & 70 \\
\hline PNS & 353 \\
\hline Petani/Pekebun & 246 \\
\hline Karyawan & 2.473 \\
\hline Perdagangan & 52 \\
\hline Buruh & 785 \\
\hline Guru/Dosen & 118 \\
\hline Wiraswasta & 1.2 .51 \\
\hline Tenaga Bid. Kesehatan & 22 \\
\hline Lainnya & 199 \\
\hline
\end{tabular}

Letak Desa Lerep yang berada di 300mdpl sehingga membuat suasana di Desa Lerep menjadi sejuk dan asri dan memiliki sumberDaya air berupa embung dan curug. Berikut ini untuk lebih jelasnya lokasi sumberdaya air di Desa Wisata Lerep. 


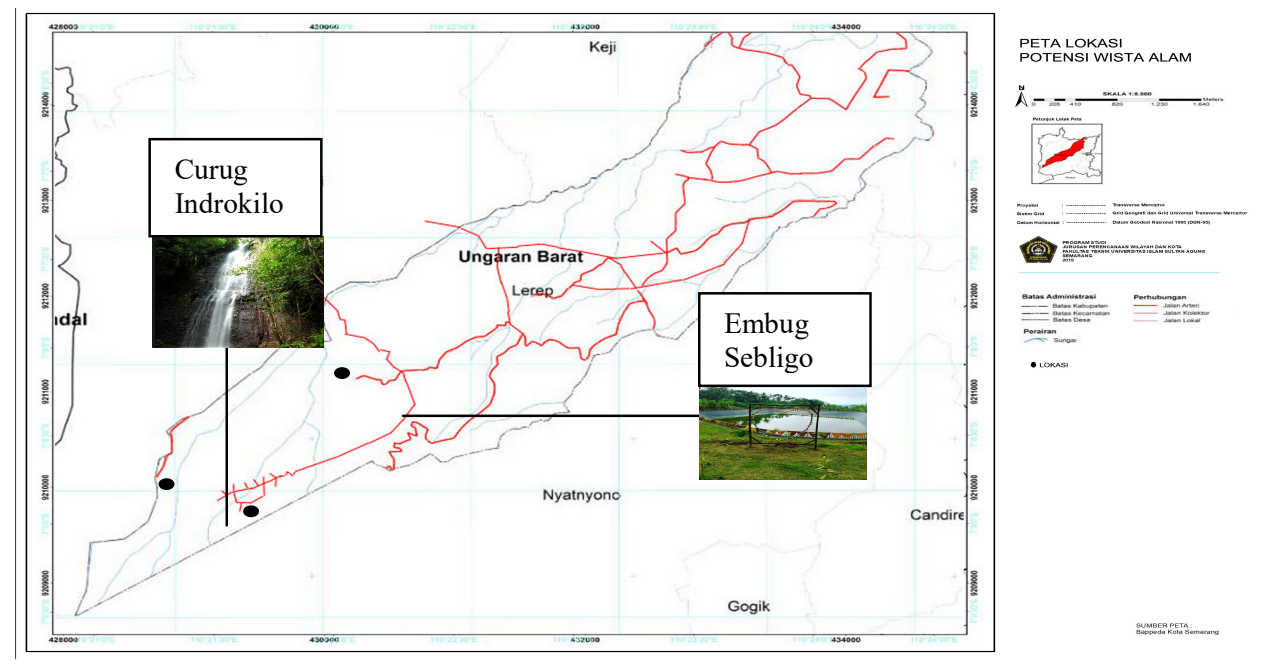

Gambar 1. Peta Sumberdaya air di Desa Lerep Sumber: Hasil Analsisi, 2019

1. Curug Indrokilo

Curug Indrokilo adalah air terjun yang berada di sebelah barat Dusun Indrokilo yang merupakan salah satu dusun yang ada di Desa Lerep. Curug Indrokilo ini merupakan wisata alam yang masih alami dan dijaga oleh masyarakat Desa Wisata Lerep untuk dijadikan potensi sumberdaya air maupun untuk Daya Tarik Wisata Alam. Aksesibiltas menuju curug adalah jalan setapak yang dapat dilalui dengan berjalan kaki.

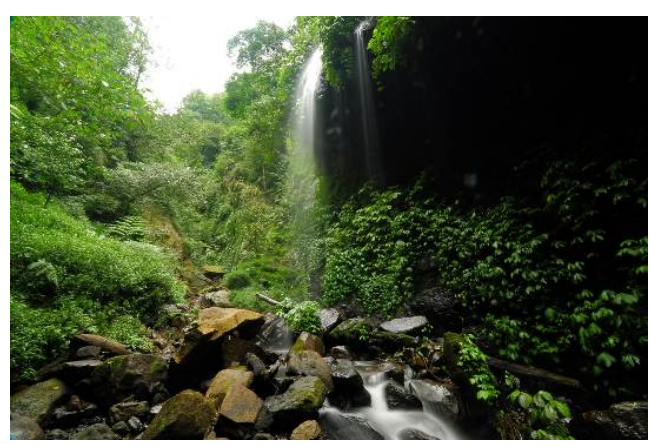

a. kenampakan sungai di dekat curug

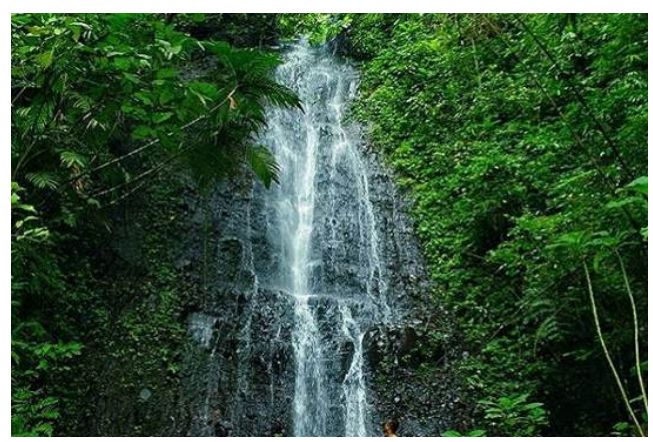

b. kenampakan ketinggian curug

Gambar 2. Curug Indrokilo di Desa Wisata Lerep Sumber: gpswisataindonesia.info

Pada saat ini masyarakat desa memnafaatkan air dari curug untuk keperluan mandi cuci dan pengairan tanaman perkebunan pada areal dibawahnya, ataupun keperluan ternak maupunperikanan air tawar. Namun curug ini juga menjadi daya tarik wisata lokal maupun asing untuk berekreasi.

Aksesibilitas menuju Curug Indrokilo ini melewati jalanan yang sangat terjal dengan banyak pepohonan rindang dan hutan bambu namun dapat dilewati oleh kendaraan 
bermotor roda dua. Terdapat tempat parkir kendaraan roda dua dan lokasi curug dari tempat parkir dapat ditempuh dengan berjalan kaki melewati perkebunan kopi milik warga Desa Wisata Lerep.

\section{Embung Sembligo}

Embung Sembligo adalah sebuah danau buatan yang terletak di tengah Desa Lerep yang dibangun oleh masyarakat Desa Lerep dengan kedalaman 5 meter dan daya tampung air sekitar Sembilan belas juta liter. Embung Sembligo ini dijadikan tempat penampungan air pada saat musim hujan tiba untuk kemudian di manfaatkan pada musim kemarau. Pembangunan Embung ini mendapatkan bantuan dari pertamina.

Air di Embung Sembligo ini dimanfaatan sebagai sumber pengairan pada area sawah yang dibudidayakan di Desa Lerep pada saat musim kemarau tiba agar pertanian tetap berjalan untuk mencukupi kebutuhan masyarakat Desa Lerep. Selain itu Embung ini juga dimanfaatan sebagai wisata air dan terdapat permainan air seperti perahu karet dan bebek air serta di sekitar Embung Sembligo ini dilengkapi dengan gazebo untuk bersantai

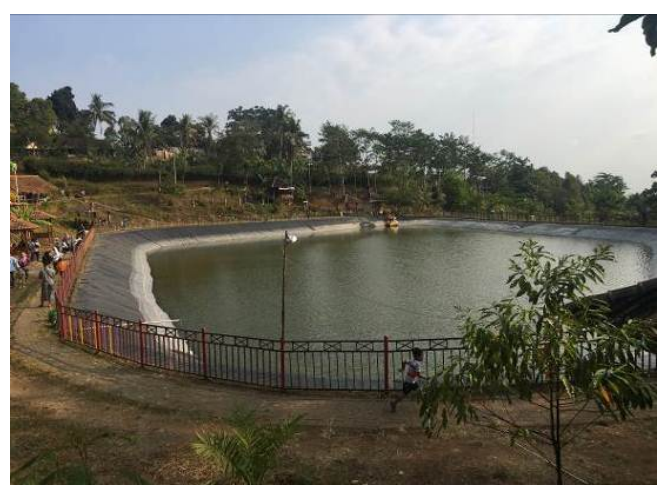

Gambar 3. Embung Sembligo di Desa Lerep Sumber: Hasil Dokumentasi, 2019

\section{Kearifan lokal “Tradisi Iriban” Masyarakat Desa Lerep}

Tradisi yang masih di kembangkan oleh warga Desa Lerep ada tiga kegiatan diantaranya iriban, kadeso dan sadranan Di Desa Lerep memiliki tradisi turun temurun yang masih dilestarikan oleh masyarakat. Tradisi tersebut menjadi ciri khas dari Desa Lerep itu sendiri dan masyarakatnya masih berupaya melestarikan karena turun temurun dari para leluhurnya.

Berikut adalah penjelasan terkait tradisi yang ada di Desa Lerep untuk lebih jelasnya. 
Jurnal Planologi Vol. 17 No. 1, April 2020

"Kearifan lokanya ada kaya semacam tradisi gitu Kegiatan iriban atau bersih mata air, ada kadeso itu semacam sedekah bumi dan juga sadaranan berdoa dan slametan yang dilakukan di makam desa” SUS/20.11.19/KL1

Kegiatan tersebut dilakukan secara bersama-sama oleh warga desa di beberapa lokasi yang ada di Desa Lerep, Berikut ini adalah uraian lengkap mengenai kearifan lokal dalam bentuk tradisi yang ada di Desa Lerep. Dalam kajian ini akan dideskripsikan kearifan lokal Iriban. Iriban dari kata Irib (bahasa Jawa artinya "emper") dalam bahasa indonesia bisa diartikan mirip. Yang dimaksud mirip dalam hal ini adalah tradisi yang dilakukan oleh orang tua ataupun nenek moyangnya melakukan tradisi.

Tradisi iriban yang ada di Desa Lerep adalah kegiatan pembersihan mata air yang dilakukan dengan serangkaian acara dan diikuti oleh warga Desa Lerep dengan tokoh masyarakat dan juga perangkat desa, untuk lebih jelasnya dapat dilihat pada kutipan wawancara berikut ini.

"Tradisi Iriban yang dijalankan untuk mengelola mata air yang ada di Desa Lerep sebagai wujud menjaganya dengan melakukan bersih-bersih mata air atau sungai dan bancaan dengan membakar ayam untuk di makan bersama-sama setelah bersih-bersih. Disini ada empat mata air tapi yang dilakukan iriban ada dua yaitu si udel dan si domble” AMD/15.11.19/KL

Tradisi Iriban adalah pembersihan sumber mata air yang ada di Desa Lerep untuk daerah irigasi mintorogo maupun sumber mata air lainya. Kegiatan pembersihan mata air ini dilakukan pada saat akan tanam padi atau pada rabu kliwon dan bulan rajab. Ada dua mata air yang dijadikan tempat untuk kegiatan iriban yaitu mata air si udel dan si domble, lokasinya berada di Dusun Soka dan Susun lerep, berikut adalah lokasi dari mata air tersebut.

Makna dari tradisi Iriban ini menunjukkan adanya bentuk pengelolaan sumberdaya air yang dilakukan oleh masyarakat secara periodik di Desa Lerep. Pengelolaan sumberdaya air mencakup pembersihan sumber mata air dari sampah yang menyumbaat aliran air; pengaturan distribusi pengairan untuk pertanian dan pemeliharaan bangunan disekitar Embung Sembligo. 


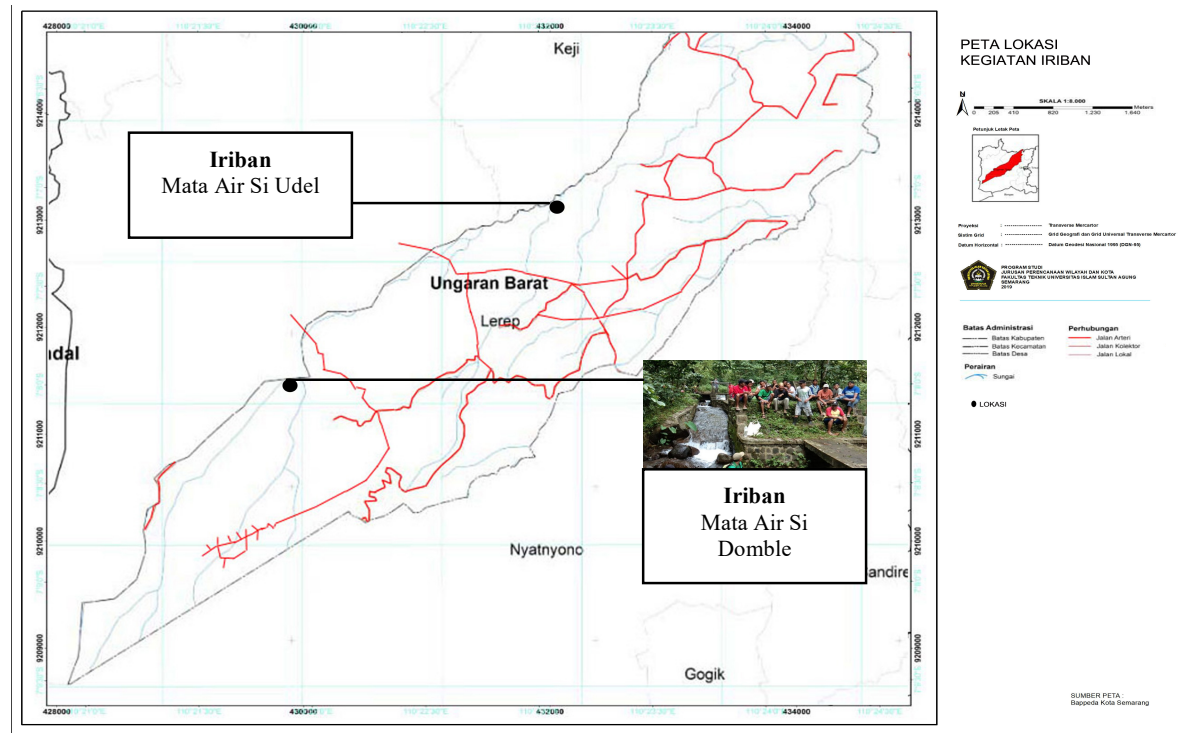

Gambar 4. Peta Lokasi Mata Air Dalam Kegiatan Iriban

Sumber:Hasil Analisis, 2020

Ritual yang dilakukan pada saat proses iriban yaitu dengan memotong ayam di atas aliran sumber air yang mengalir. Sehingga darah dari ayam yang dipotong akan mengalir dengan air tersebut. Maksud dari kegiatan ini adala sebagi bentuk pembersihan sumber mata air yang ada di Desa Wisata Lerep. Selanjutnya ayam tersebut akan dibakar dan dimasak sedangkan yang lainnya membersihkan sumber mata air dan sekitarnya Selanjutnya setelah besih-bersih diadakan selamatan dengan doa bersama kemudian makan bersama para warga dan sesepuh desa yang melakukan ritual iriban tersebut. Hal tersebut sesuai dengan kearifan lokal Tunggu Gunung Kudu Wareg dimana memanfaatkan kegiatan wisata dengan tetap menjaga kelestarian lingkungannya. untuk lebih jelasnya dapat dilihat pada kutipan wawancara berikut ini.

“Acaranya itu ada sembelih ayam di atas sumber air, nanti darah ayam itu ikut aliran airnya, itu maksudnya biar bersih aliran airnya. Ayam yang udah di sembelih tadi di masak, di kasih bumbu sedehana terus dimasaknya dibakar, nanti kita kita makan bareng-bareng di atas daun pisang, ada urap juga itu penting. Namanya itu sego iriban” SUS/20.11.19/KL3

Dimana untuk melengkapi tradisi ini digelar Bancaan Klubanan terdiri dari nasi urap dilengkapi dengan ayam kampung yang dibakar dengan ditusuk bambu sebelum dibakar dibumbui terlebih dahulu. Selain Ayam Kampung yang berjumlah sekitar 70 ekor, iriban juga menyajikan daun kopi muda yang dibakar dalam kolongan bambu kemudian 
dicampur dengan nasi urap.. Tradisi iriban ini juga merupakan wujud syukur atas pembersihan mata air yang ada di Desa Wisata Lerep.
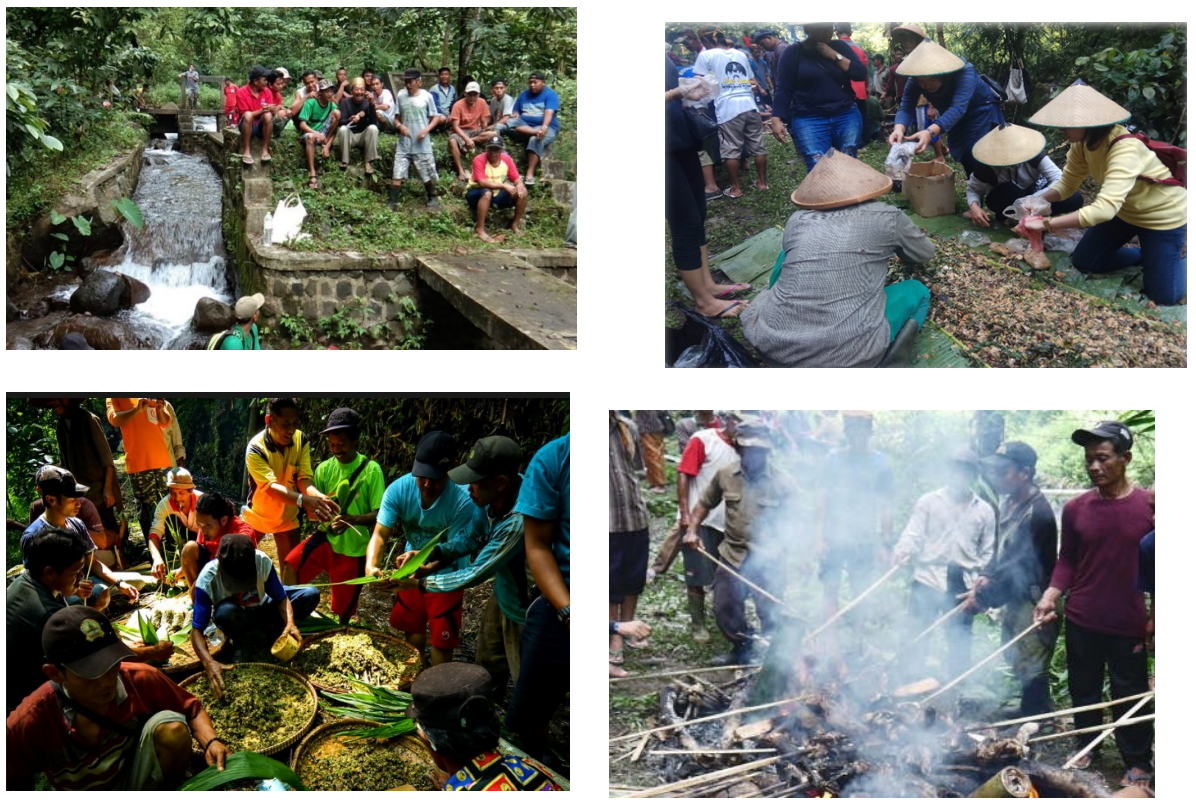

Gambar 5. Kegiatan Iriban Desa Wisata Lerep Sumber: Profil Deswita Lerep,2019

Terlepas dari kegiatan tradisi Iriban yang dilaksanakan masyarakat, makna dari kegiatan ini yaitu adanya kebersamaan masyarakat untuk memperhartikan keberadaan sumberdaya air di Desa Lerep. Melalui kearifan lokal ini, masyarakat melakukan bersihbersih sumber air,mebersihkan embung, memperbaiki saluran pengairan, menghilangkan sumbatan-sumbatan sampah yang menghambat aliran air. Dengan demikian maka yang air berasal dari 2 sumber mata air akan tetap terjaga, dan berfungsi sebagai pengairan tanaman pertanian pangan maupun perkebunan yang ada di kawasan bawahnya. Sedangkan embung tetap dikelola sebagai penampungan air di musim penghujan, sehingga pada musim kemarau embung ini dapatdimanfaatkan untuk pengairan pertanian.

Menjelang musim tanam, masyarakat mempersiapkan prasarana air untuk budidaya tanaman pertanian. Pada saat musim tanam khususnya masyarakat petani tidak mengalami kekurangan air untu budidaya tanaman. Demikian pula kebutuhan air utuk rumah tangga masyarakat dapat terpenuhibaik dari aliran air yang dari curug maupun air dari embung Sembligo. 
Jurnal Planologi Vol. 17 No. 1, April 2020

Available : http://jurnal.unissula.ac.id/index.php/psa

\section{KESIMPULAN DAN SARAN}

\subsection{Kesimpulan}

Kehidupan masyarakat Desa Lerep erat kaitannya dengan aktivitas tradisi yang menjadi kearifan loka masyarakat desa. Bentuk kearifan lokal Iriban merupakan upaya masyarakat dalam mengelola sumberdaya air bagi kehidupan masyarakat baik untuk kepentingan rumah tangga,maupun pertanian. Makna dari tradisi Iriban ini menunjukkan adanya bentuk pengelolaan sumberdaya air yang dilakukan oleh masyarakat secara periodik di Desa Lerep. Pengelolaan sumberdaya air mencakup pembersihan sumber mata air dari sampah yang menyumbaat aliran air; pengaturan distribusi pengairan untuk pertanian dan pemeliharaan bangunan disekitar Embung Sembligo. Dengan demikian sumberdaya air di Desa Lerep senantiasa terjaga.

\subsection{Saran}

- Pemerintah daerah perlu melestarikan kearifan lokal masyarakat. Melalui kearifan lokal dapat mejadi sarana dalam pelaksanaan program pembangunan di wilayah pedesaan.

- Perlunya dikaji partisipasi generasi milenial dalam pembangunan berbasis kearifan lokal.

\section{DAFTAR PUSTA}

Abdullah, Idi. (2011). Sosiologi Pendidikan Individu, Masyarakat dan Pendidikan. Jakarta: Rajawali Press

Anonim, 2019. Kecamatan Ungaran Barat dalam Angka. Badan Pusat Statistik, Kabupaten Semarang

Aziz, Agus. (2015). Studi Dinamika Masyarakat Desa Dalam Pembangunan Berbasis Kearifan Lokal. Salatiga : Thesis Pascasarjana Magister Studi Pembangunan Universitas Kristen Satya Wacana

Basrowi, Suwandi. (2008). Memahami Penelitian Kualitatif. Jakarta: Rineka Cipta

Muhadjir, Noeng. (1996). Metodologi Penelitian Kualitatif Pendekatan Positivistik, Rasionalistik, Phenomenologik dan Realisme Metaphisik Telaah Studi Teks dan Penelitian Agama. Yogyakarta: Bayu Indra Grafika.

Mohamad Wakhyudin dan Juhadi, Heri Tjahjono (2017). Kearifan Lokal Sebagai Upaya Ketahanan Pangan Di Desa Lerep, Kecamatan Ungaran Barat, Kabupaten Semarang Tahun Jurusan Geografi, Fakultas Ilmu Sosial, Universitas Negeri Semarang, Indonesia 
Jurnal Planologi Vol. 17 No. 1, April 2020

Available : http://jurnal.unissula.ac.id/index.php/psa

Nasiwan, dkk. (2012). Dasar-Dasar Ilmu Politik. Yogyakarta: Ombak

Sedyawati, Edi. (2006). Budaya Indonesia: Kajian Arkeologi, Seni dan Sejarah. Jakarta: Raja Grafindo Persada.

Sibarani, Robert. (2012). Kearifan Lokal: Hakikat, Peran dan Metode Tradisi Lisan. Jakarta: Asosiasi Tradisi Lisan.

Sartika, M. (2018). Kajian Praktik Budaya Religi di Desa Nyatnyono, 20(1), 109-128. 